\title{
MộT SỐ YẾU TỐ LIÊN QUAN ĐẾN KHỞI PHÁT, MỨC Độ NĂNG VÀ KẾT QUẢ ĐIỀU TRI NHIỄM TOAN CETON DO ĐÁI THÁO ĐƯỜ'NG TYPE 1 Ở TRẺ EM VÀ VỊ THÀNH NIÊN
}

\author{
Vũ Chí Dũng', Trần Quang Thanh²
}

\section{TÓM TẮT}

Đái tháo đường (ĐTĐ) type 1 là một trong những bệnh lý nội tiết phổ biến nhất ở trẻ em. Nhiểm toan ceton (NTCT) là một biến chứng cấp hay gặp ở bệnh nhi mắc ĐTĐ type 1 , đây là biến chứng rất nặng của bệnh, gây tử vong nếu không được chẩn đoán và điêu trị kịp thời. Ớ trẻ nhỏ, đặc biệt dưới 2 tuổi, khả năng tiếp cận với các dịch vụ y tế thấp, dân tộc thiểu số, và chẩn đoán sai là các yếu tố nguy cơ của NTCT. Mục tiêu: mô tả một số yếu tố nguy cơ, mức độ nặng NTCT của bệnh nhi ĐTĐ type 1 , và nhận xét kết quả điều trị NTCT. Đối tượng nghiên cứu: 212 bệnh nhi được chẩn đoán đái tháo đường type 1 lần đâu từ tháng 6/2015 đến 6/2020 tại bệnh viện Nhi Trung ương. Phương pháp: nghiên cứu một loat ca bênh. Kết quả: $60 / 212$ bệnh nhân $(28,3 \%)$ có NTCT; nồng độ C-peptid dưới $1,1 \mathrm{ng} / \mathrm{ml}$ làm tăng nguy cơ NTCT lên 5,13 lần (95\% CI:1,72-15,29), tăng nguy cơ NTCT mức độ nặng lên 2,13 lần, (95\% CI:0,20-22,21); chẩn đoán nhầm làm tăng 6,42 lần nguy cơ NTCT mức độ nă̆ng, (95\% CI:1,20-34,19). Thời gian hết toan trung bình là 22,5 giờ. Suy thận cấp gặp ở $30 \%$ bệnh nhân NTCT. Khônng có bênh nhân tử vong. Kết luận: Bệnh nhân được chẩn đoán ĐTĐ type 1 lần đầu ở Bệnh viện Nhi Trung ương có tỷ lệ NTCT cao. Nồng độ C-peptid dưới $1,1 \mathrm{ng} / \mathrm{ml}$, chẩn đoán nhầm là các yêu tố gây gia tăng nguy cơ và mức độ NTCT. Suy thận cấp là biến chứng hay gặp trong NTCT.

Tư khóa: Đái tháo đường type 1, nhiễm toan ceton do đái tháo đường

\section{SUMMARY \\ FACTORS ASSOCIATED WITH PRESENCE AND SEVERITY AND OUTCOME OF DIABETIC KETOACIDOSIS IN CHILDREN AND \\ ADOLESCENTS WITH TYPE 1 DIABETES}

Type 1 diabetes mellitus (T1MD) is one of the most common endocrine diseases in children. Diabetic ketoacidosis (DKA) is the most serious life-threatening acute complication of T1MD. Younger age, particularly $<2$ years, low accessibility to medical care, ethnic minority groups and diagnostic error were identifed as risk factors for DKA at T1DM diagnosis. Determining the risk factors for developing DKA plays an important role in diagnosing, treating and reducing the rate and serevity of the disease.

\section{${ }^{1}$ Bệnh viện Nhi Trung ương}

${ }^{2}$ Đại học Y Hà Nội

Chịu trách nhiệm chính: Vũ Chí Dũng

Email: dungvu@nch.org.vn

Ngày nhận bài: 25.12.2020

Ngày phản biên khoa học: 15.2.2021

Ngày duyệt bài: 25.2.2021
Objective: to describe the risk factors and outcome of DKA in children and adolescents. Subjects: 212 patients with type 1 diabetes at diagnosis at the National Children's Hospital (NCH) from 6/2015 to 6/2020. Methods: case series study. Results: 212 patients with type 1 diabetes at diagnosis at the $\mathrm{NCH}$ from $6 / 2015$ to $6 / 2020$. Sixty patients $(28.3 \%)$ were diagnosed with DKA; serum C-peptide levels were lower $1,1 \mathrm{ng} / \mathrm{ml}$ increased the risks for DKA (OR, 5,13; $95 \% \mathrm{CI}, 1,72-15,29)$, increased the risks for severe DKA (OR, 2,13; 95\% CI, 0,20 - 22,21), diagnostic error increased the risks for severe DKA (OR, 6,42; $95 \%$ CI, 1,20-34,19). The mean time for the arterial blood gases to become normal was 22,5 hours. Acute kidney injury developed in 15 patients $(30 \%)$. There were no deceased patients. Conclusion: The rate of DKA in patients with T1DM for the first time at $\mathrm{NCH}$ was high. Serum C-peptide levels were lower $1,1 \mathrm{ng} / \mathrm{ml}$, diagnostic error increased the risks for DKA and severity of DKA. Acute kidney injury is a common complication of DKA.

Keywords: Type 1 diabetes, Diabetic ketoacidosis

\section{I. ĐẶT VẤN ĐỀ}

Đái tháo đường (ĐTÐ) type 1 là một trong những bệnh lý nội tiết phổ biến nhất ở trẻ em [1]. Bệnh có xu hướng gia tăng trên toàn thế giới với khoảng 96000 trẻ mắc mới mỗi năm [2]. Nhiếm toan ceton (NTCT) là một biến chứng cấp hay gă̆p ở bệnh nhi mắc ĐTĐ type 1 , đây là một biến chứng rất nặng của bệnh, gây tử vong nểu không được chẩn đoán và điều trị kịp thời. Tỷ lệ NTCT lúc mới chẩn đoán dao động từ $12,8 \%$ đến $80 \%$, cao nhất ở các tiểu vương quốc Ả rập thống nhất, $A$ rập Xê út và Rumani, trong khi thấp nhất ở Thụy Điển, cộng hòa Slovakia và Canada [3]. Các nghiên cứu đã chỉ ra yếu tố nguy cơ cao của NTCT bao gồm trẻ dưới 2 tuổi, khả năng tiếp cận với các dịch vụ y tế thấp, dân tộc thiểu số, trì hoãn chẩn đoán [4]. Xác định được các yếu tố nguy cơ của ĐTĐ type 1 góp phần chẩn đoán, điều trị và hạn chế các biến chứng của bệnh.

Ở Việt Nam đã có một số công trình nghiên cứu về ĐTÐ và toan ceton do ĐTÐ ở trẻ em, biến chứng mạn ở trẻ ĐTĐ type 1 . Tuy nhiên, những công trình này phần lớn được tiến hành với cỡ mẫu nhỏ, trong giai đoạn số lượng bệnh nhân mới chẩn đoán còn thấp, triệu chứng lâm sàng điển hình có ở đa số các trường hợp nhưng vẫn có trường hợp bỏ sót và chẩn đoán nhầm. 
Đứng trước môt bênh lý mà tiến triển nhanh ở trẻ nhỏ, biến chứng cấp dễ chẩn đoán nhầm và cần được điều trị cấp cứu như vậy, chúng tôi tiến hành nghiên cứu với mục tiêu: Mô tả môt số yếu tố nguy cơ liên quan đến khởi phát, mức độ nạnng và nhận xét kêt quả điều trị nhiếm toan ceton do ĐTÐ type 1 ở trẻ em và vị thành niên.

\section{II. ĐỐI TƯợNG VÀ PHƯƠNG PHÁP NGHIÊN CỨU \\ 1. Đối tượng}

Tiêu chuẩn lựa chọn: Tất các các bệnh nhân được chẩn đoán ĐTĐ type 1 theo tiêu chuẩn của Hiệp hội Đái tháo đường Hoa Kỳ năm 2018 [5].

Tiêu chuân loại trừ: các bệnh nhân không đồng ý tham gia nghiên cứu hoặc hồ sơ không đầy đủ.

\section{Phương pháp}

2.1. Thiết kế nghiên cứu. Nghiên cứu một loạt ca bệnh, hồi cứu và theo dõi dọc tiến cứu. Mổ tả các biểu hiện lâm sàng, các xét nghiệm hóa sinh và khai thác tiền sử, bệnh sử, quy trình tiếp cận các dịch vụ y tế, điều trị và kết quả điều trị của các bệnh nhân NTCT.

2.2. Cỡ mẫu. Cỡ mẫu thuận tiện, tất cả bệnh nhân đủ tiêu chuẩn đều được đưa vào phân tích trong thời gian nghiên cứu từ tháng 6/2015 đến hết tháng 6/2020 tại khoa Nội tiết Chuyển hóa - Di truyên, Bệnh viện Nhi Trung Ương.

\subsection{Chỉ số và biến số nghiên cứu}

Đặc điểm đối tượng nghiên cứu: tuổi (năm), giới (nam, nữ), dân tộc, tiền sử gia đình (có bố me, anh chị em ruột bị ĐTÐ), địa dư (thành thị, nông thôn), trình độ văn hóa của bố mẹ.

Khai thác tiền sử, bệnh sử, khám lâm sàng toàn diện: cân nặng, chiều cao, chức năng sống (nhịp thở, mạch, huyết áp, SpO2), mức độ mất nước và khám toàn diện các bộ phận.

Các xét nghiệm sinh hóa và huyết học gồm: glucose, khí máu, urea, creatinine, điện giải đồ, canxi, phospho, insulin, C-peptid, HbA1c, công thức máu, CRP; ceton niệu.

Các dữ liệu bao gồm cả tiến cứu và hồi cứu hồ sơ bệnh án.

2.4. Xử lý số liệu. Thu thập số liệu theo biểu mẫu, xử lý bằng phần mềm SPSS 16.0 với test Chi bình phương và test Fisher (kiểm định 2 phía) với $20 \%$ số ô có tần số mong đợi nhỏ hơn 5; so sánh giá trị trung bình biến không chuẩn của các nhóm sử dụng test Kruskal-wallis $\mathrm{H}$. Giá trị $\mathrm{p}<0,05$ được coi là ý nghĩa thống kê.

3. Đạo đức nghiên cứu. Đề tài đã được Hội đồng đạo đức trong Nghiên cứu sinh y của
Bệnh viện Nhi Trung ương chấp thuận theo chứng nhận chấp nhận số 195/BVNTW-VNCSKTE năm 2020.

\section{KẾT QUẢ NGHIÊN CỨU}

Trong thời gian 5 năm từ 6/2015 - 6/2020 có 212 bệnh nhân ĐTĐ type 1 phát hiên lần đầu được điều trị tại khoa Nội tiết - Chuyển hoá - Di truyền, bệnh viện Nhi Trung ương. 60/212 bệnh nhân $(28,3 \%)$ NTCT, trong đó 25 bênh nhân NTCT mức độ nặng, 8 bệnh nhân NCTC mức độ trung bình và 27 bệnh nhân NCTC mức độ nhẹ.

Tuổi trung bình NTCT là $8,38 \pm 3,57.32 / 60$ bệnh nhi $(53,3 \%)$ là nữ, 28/60 bệnh nhi $(46,7 \%)$ là nam. Không bệnh nhân nào có tiền sử gia đình bao gồm bố me hoăc anh chị em ruột bị ĐTĐ. $9 / 60$ bệnh nhân (15\%) bị chẩn đoán nhầm dẫn đến chậm trễ trong việc điều trị. 39/60 bệnh nhân (65\%) ở nông thôn, $9 / 60$ bệnh nhân $(15 \%)$ có trình độ văn hóa của bố mẹ dưới lớp $12 ; 4 / 60$ bệnh nhân $(6,7 \%)$ là người dân tộc thiểu số.

3.1. Yếu tố nguy cơ bệnh nhân nhiễm toan ceton

3.1.1. Mối liên quan giữa các yếu tố và nguy cơ nhiễm toan ceton

Bảng 1. Môî liên quan giữa các yếu tố và nguy cơ nhiếm toan ceton

\begin{tabular}{|c|c|c|c|}
\hline \multirow{2}{*}{ Yếu tố } & \multicolumn{2}{|c|}{ Nhiêm toan } & OR (95\% \\
\cline { 2 - 3 } & Có & Không & CI) \\
\hline Tuổi dưới 3 tuổi & $7 / 60$ & $33 / 152$ & $\begin{array}{c}0,48 \\
(0,20-1,14)\end{array}$ \\
\hline Giới nữ & $32 / 60$ & $77 / 152$ & $\begin{array}{c}1,11 \\
(0,61-2,03)\end{array}$ \\
\hline $\begin{array}{c}\text { Địa dư (nông } \\
\text { thôn) }\end{array}$ & $39 / 60$ & $91 / 152$ & $\begin{array}{c}1,25 \\
(0,67-2,32)\end{array}$ \\
\hline $\begin{array}{c}\text { Dân tộc thiểu số } \\
\text { Trình độ học vấn } \\
\text { bố mẹ (dưới lớp } \\
\text { 12) }\end{array}$ & $4 / 60$ & $12 / 152$ & $\begin{array}{c}0,83 \\
(0,26-2,70)\end{array}$ \\
\hline $\begin{array}{c}\text { Nồng độ C peptid } \\
\text { (dưới 1,1 ng/ml) }\end{array}$ & $41 / 45$ & $82 / 123$ & $\begin{array}{c}0,55 \\
(0,25-1,22) \\
5,13(1,72- \\
15,29)\end{array}$ \\
\hline
\end{tabular}

Nhận xét: Khả năng nhiếm toan ceton của trẻ nữ cao hơn 1,11 lần so với trẻ nam, 95\% CI từ $0,61-2,03$; vùng nông thôn có khả năng nhiễm toan ceton cao hơn 1,23 lần so với thành thị, 95\% CI từ 0,67 - 2,32. Nồng độ C-peptid dưới $1,1 \mathrm{ng} / \mathrm{ml}$ làm tăng nguy cơ NTCT lên 5,13 lần, có ý nghĩa thống kê với 95\% CI từ 1,72 - 15,29.

3.1.2. Mối liên quan giữa các yếu tố và nguy cơ nhiễm toan ceton mức độ nặng

Bảng 2. Mối liên quan giữa các yếu tồ và nguy cơ nhiếm toan ceton mức độ nặng 


\begin{tabular}{|c|c|c|c|}
\hline \multirow{2}{*}{ Yếu tố } & \multicolumn{2}{|c|}{$\begin{array}{c}\text { Mức độ nhiêm } \\
\text { toan }\end{array}$} & OR (95\% \\
\cline { 2 - 4 } & Nặng & $\begin{array}{c}\text { Nhẹ và } \\
\text { trung bình }\end{array}$ & $\begin{array}{c}1,06(0,22 \\
-5,2)\end{array}$ \\
\hline Tuổi dưới 3 tuổi & $3 / 25$ & $4 / 35$ & $\begin{array}{c}0,91(0,33 \\
-2,56)\end{array}$ \\
\hline Giới nữ & $13 / 25$ & $19 / 35$ & $\begin{array}{c}0,27(0,09 \\
-0,83)\end{array}$ \\
\hline $\begin{array}{c}\text { Địa dư (nông } \\
\text { thôn) }\end{array}$ & $12 / 25$ & $27 / 35$ & $\begin{array}{c}0,35(0,07 \\
-1,84)\end{array}$ \\
\hline Dân tộc thiểu số & $2 / 25$ & $7 / 35$ & $0,44(0,04$ \\
\hline Trình độ học vấn & $1 / 25$ & $3 / 35$ & 0 \\
\hline
\end{tabular}

\begin{tabular}{|c|c|c|c|}
\hline $\begin{array}{c}\text { bố mẹ } \\
\text { (dưới lớp 12) }\end{array}$ & & & $-4,54)$ \\
\hline Chẩn đoán nhầm & $7 / 25$ & $2 / 35$ & $\begin{array}{c}6,42(1,20 \\
-34,19)\end{array}$ \\
\hline $\begin{array}{l}\text { Nồng độ C peptid } \\
\text { (dưới 1,1 ng/ml) }\end{array}$ & $17 / 18$ & $24 / 27$ & $\begin{array}{c}2,13(0,20 \\
-22,21) \\
\end{array}$ \\
\hline
\end{tabular}

Nhận xét: Khả năng nhiếm toan ceton mức độ nặng của nhóm bị chẩn đoán nhầm cao hơn 6,4 lần so với nhóm được chẩn đoán đúng ngay từ đâu, có ý nghĩa thống kê với $95 \%$ CI từ 1,72 15,29 . Nồng độ C-peptid dưới $1,1 \mathrm{ng} / \mathrm{ml}$ làm tăng nguy cơ NTCT mức độ nặng lên 2,13 lần, không có ý nghĩa thống kê với 95\% CI từ 0,20 - 22,21.

\subsection{Kết quả điều trị và biến chứng của nhiễm toan ceton}

3.2.1. Kết quả điêu trị nhiếm toan ceton

Bảng 3. Kêt quả điều trị nhiếm toan ceton

\begin{tabular}{|c|c|c|c|c|c|}
\hline \multirow{2}{*}{ Tham số } & \multirow{2}{*}{ Tổng } & \multicolumn{3}{|c|}{ Mức độ nhiêm toan ceton } & \multirow{2}{*}{ p } \\
\cline { 3 - 5 } & & Nhẹ & Trung bình & Nặng & \\
\hline Thời gian hết toan (giờ) & 22,50 & 10,96 & 16,43 & 35,96 & 0,01 \\
\hline Thời gian duy trì insulin (giờ) & 33,87 & 19,13 & 26,14 & 51,06 & 0,002 \\
\hline Thời gian truyền dịch (giờ) & 34,45 & 19,26 & 26,29 & 52,25 & 0,02 \\
\hline Thời gian nằm viện (ngày) & 12,02 & 9,93 & 13,25 & 13,88 & 0,044 \\
\hline
\end{tabular}

Nhận xét: Thời gian hết toan trung bình là 22,50 giờ. Thời gian điều trị bằng insulin tĩnh mach trung bình là 33,87 giờ. Thời gian truyền dịch trung bình là 34,45 giờ. Thời gian nằm viện trung bình là 12,02 ngày. Sự khác biệt có ý nghĩa thống kê giữa 3 nhóm về thời gian hết toan trung bình, thời gian truyền insulin trung bình, thời gian truyền dịch trung bình và thời gian nằm viện trung bình $(p<0,05)$.

\subsubsection{Biến chứng nhiếm toan ceton}

Bảng 4. Biến chứng của nhiếm toan ceton

\begin{tabular}{|c|c|c|c|c|c|}
\hline \multirow{2}{*}{ Biến chứng } & \multicolumn{3}{|c|}{ Mức độ nhiêm toan ceton } & \multicolumn{2}{c|}{ Tống } \\
\cline { 2 - 6 } & Nhe & Trung bình & Nă̆ng & $\mathbf{n}$ & Tỷ lệ (\%) \\
\hline Suy thận & 9 & 2 & 7 & 18 & 30 \\
\hline Hạ glucose & 1 & 2 & 3 & 6 & 10 \\
\hline Giảm kali máu & 4 & 1 & 5 & 10 & 16,7 \\
\hline Phù não & 0 & 0 & 1 & 1 & 1,7 \\
\hline
\end{tabular}

Nhận xét: Không có bệnh nhân nào tử vong trong nghiên cứu. Trong đó nhiều nhất là suy thận cấp, có 18 bệnh nhân (30\%). Tiếp đến là biến chứng giảm kali máu với 10 bệnh nhân $(16,7 \%)$; hạ glucose với 6 bệnh nhân (10\%). Có 1 bệnh nhân bị phù não (1,7\%).

\section{BÀN LUẬN}

Tuổi trung bình của bệnh nhân NTCT lúc chẩn đoán là $8,38 \pm 3,57$ tuổi; $53,3 \%$ là nữ. Kết quả này tương đương với nghiên cứu của Lee và CS (2016) tại Hàn Quốc trên 177 bệnh nhân, tuổi trung bình là $8,80 \pm 4,30$ tuổi với $55,9 \%$ là nữ [1]. ĐTÐ type 1 có thể khởi phát ở bất cứ độ tuối nào, tuy nhiên $45 \%$ xảy ra trước 10 tuổi, trong đó có hai khoảng tuổi hay khởi phát là 5-7 tuổi và giai đoạn đầu của dậy thì. ĐTĐ type 1 là một bệnh lý đa gen, không liên quan đến NST giới tính nên tỷ lệ mắc ở hai giới là như nhau.

Không có bệnh nhân NTCT nào có tiền sử gia đình gồm bố, mẹ hay anh chị em ruột bị ĐTĐ. Usher-Smith và cộng sự (2011) đã thấy rằng ở những gia đình có người thân bi mắc ĐTĐ, tần suất NTCT ở trẻ giảm [6]. Có thể giải thích được vấn đề này là do khi không có ai bị bệnh, gia đình bệnh nhân ít nghĩ tới ĐTÐ do đó gẩy chậm trễ trong công tác chẩn đoán và điều trị.

Usher-Smith và CS (2011) đã chỉ ra các yếu tố nguy cơ gia tăng khả năng NTCT ở bệnh nhân lần đâu được chẩn đoán ĐTĐ type 1: tuổi < 2 tuổi, chẩn đoán nhầm, chậm trề trong điều trị, dân tộc thiểu số và điều kiện kinh tễ xã hội kém [6]. Lee và cộng sự (2016) tại Hàn Quốc trên 177 bênh nhẩn thấy: nguy cơ NTCT của bệnh nhi dưới 3 tuổi cao hơn 3,77 lần từ 3-12 tuổi; có nhiếm trùng tăng 3,16 lần [1]. Nghiên cứu của chúng tôi không thấy các yếu tố: tuổi nhỏ dưới 3 tuổi, dân tộc thiểu số, trình độ học vấn là yếu tố 
gia tăng nguy cơ NTCT. Giới nữ, vùng nông thôn có nguy cơ NTCT cao hơn lần lượt là 1,11 và 1,25 lần, nhưng không có ý nghĩa thống kê. Có thể do nghiên cứu có cơ mẫu nhỏ (chỉ có 60 bệnh nhân NTCT).

Nồng độ C-peptid dưới $1,1 \mathrm{ng} / \mathrm{ml}$ làm tăng nguy cơ NTCT lên 5,13 lần và gia tăng nguy cơ NTCT mức độ nặng lên 2,13 lần. Nồng độ $\mathrm{C}-$ peptid bình thường trong khoảng $1,1-4,4$ $\mathrm{ng} / \mathrm{ml}$. C-peptid là một chuỗi đơn có 31 acid amin, nối chuỗi $A$ và chuỗi $B$ của insulin trong phân tử proinsulin. C-peptid và insulin được tiết vào tuần hoàn với tỷ lệ tương đương nhau. Cpeptid phản ảnh một cách gián tiếp nhưng trung thành về nồng độ insulin nội sinh.

Chẩn đoán nhầm gây chậm trễ trong điều trị gây gia tăng 6,42 lần nguy cơ NTCT mức độ nặng, 95\% CI $(1,20$ - 34,19) có ý nghĩa thống kê. Usher-Smith và cộng sự (2011) cho thây chẩn đoán nhầm làm tăng 3,35 lần nguy cơ NTCT [6]. Triệu chứng bênh NTCT diễn biến nhanh, không đặc hiệu, dễ bị nhầm với bệnh lý khác, đặc biệt vào viện các biểu hiện: thở nhanh, li bì, rối loạn ý thức sẽ dễ gây nhầm lẫn với các bệnh khác như viêm phổi (do thở nhanh Kussmaul), tiêu chảy cấp, bệnh lý tiết niệu (do đái nhiêu), viêm não màng não (do thay đổi ý thức).

Thời gian hết toan trung bình là 22,50 giờ tương đương với Varshney (2015) ở Ấn Độ khi thời gian hết toan trung bình là 26 giờ [7]. Trong khoảng 24 giờ sau khi bắt đầu điều trị bệnh nhân sẽ hết toan. Có thể là do cơ thể trẻ em đáp ứng tốt, cải thiện nhanh khi điều trị bằng insulin tĩnh mach và bù dịch.

Thời gian điêu trị bằng insulin tĩnh mạch trung bình là 33,87 giờ. So sánh với một số nghiên cứu khác trên thế giới, nhiều hơn Naeem (2015) ở A rập Xê út là 23,8 giờ [8] và thấp hơn của Rosenbauer (2002) ở Đức là 55 giờ [9]. Có sự khác nhau như vậy có thể là do tỷ lệ mức độ nhiễm toan ceton trong các nghiên cứu là khác nhau, càng nhiều bệnh nhân nặng thời gian truyền insulin càng dài. Có thể có nhiều yếu tố tác động và cần có thêm các nghiên cứu tiếp theo để có thể khẳng định được mối liên quan những yếu tố này và thời gian truyền insulin tînh mạch.

Thời gian truyền dịch trung bình là 34,45 giờ. Kết quả này thấp hơn của Lone (2010) ở Pakisstan là $44.96 \pm 8.9$ giờ [10]; Rosenbauer (2002) ở Đức là 54,6 giờ [9]. Thới gian truyền dịch cũng thay đổi tùy vào mức độ nặng của NTCT, càng nhiều bệnh nhân NTCT nă̆ng thì thời gian truyền dịch càng dài. Cũng có thể do nghiên cứu của chúng tôi được tiến hành trên nhóm bệnh nhân những năm gần đây và việc chẩn đoán và điều trị được cải thiện nhiều so với các nghiên cứu trước, do vậy thời gian truyền dịch cũng ngắn hơn trong các nghiên cứu của các tác giả trên.

Thời gian nằm viện trung bình là 12,02 ngày. Kết quả này thấp hớn của trong nghiên cứu của Rosenbauer (2002) là 18,9 ngày [9]. Như vậy, trung bình trong vòng hai tuần bệnh nhân của chúng tôi sẽ được xuất viện. Thời gian nằm viện cũng phụ thuộc vào mức độ NTCT, càng NTCT năng thì thời gian nằm viện càng lâu. Điều kiên kinh tế xã hội được nâng cao góp phần cải thiện khả năng chẩn đoán, do đó thời gian điều trị cũng được giảm xuống.

Suy thân cấp là biến chứng hay găpp, nguyên nhân chủ yếu là do thiếu dịch, do đó khi bổ sung đầy đủ lượng dịch thiếu bệnh nhân đều hết tình trạng suy thận. Đã có những nghiên cứu về tình trạng suy thận cấp trong nhiễm toan ceton, cho thấy không có bệnh nhân nào tử vong hay để lại biến chứng lâu dài về thận [11]. Suy thận trong toan ceton không phải là một biến chứng quá phổ biến và thường cũng nhanh chóng hồi phục, nhưng cũng có những trường hợp bệnh nhân có thể rất nặng khi phối hợp thêm các yếu tố khác như nhiễm trùng.

Hạ glucose cũng là biến chứng hay gặp, chiếm $10 \%$ trong nghiên cứu của chúng tôi. Khi sử dụng insulin truyền tĩnh mạch, có thể gặp tình trạng bệnh nhân bị hạ glucose máu quá nhanh, thậm chí xuống mức dưới 3,9 mmol/l. Vì thế cần giám sát chặt chẽ nồng độ glucose máu hàng giờ để có điều chỉnh phù hợp.

Hạ kali máu là biến chứng cần chú ý. 10 bệnh nhân $(16,7 \%)$ có hạ kali máu. Trẻ bị NTCT bị thiếu hưt tổng lượng kali trong cơ thể vào khoảng từ 3 đến $6 \mathrm{mmol} / \mathrm{kg}$ [4]. Sự mất kali chủ yếu là từ nguồn nội bào. Kali nội bào bị cạn kiệt do ưu trương, nhiếm toan, và quá trình phân giải glycogen và phân giải protein thứ phát do thiếu insulin cũng làm kali ra khỏi tế bào. Kali là mất khỏi cơ thể do nôn và do hậu quả của bài niệu thẩm thấu. Suy giảm thể tích tuần hoàn gấy tăng aldosteron thứ phát, góp phần tăng thải kali qua nước tiểu. Tuy nhiên, khi xét nghiệm nồng độ kali huyết thanh có thể bình thường, tăng hoặc giảm. Sử dụng insulin và điều chỉnh tình trang nhiễm toan sẽ đẩy kali trở lại tế bào, làm giảm huyết thanh nồng độ kali. Nồng độ kali huyết thanh có thể giảm đột ngột, khiến bệnh nhân bị rối loạn nhịp tim và tử vong nhanh chóng. Xét nghiệm điền giải đồ mỗi 2-4 giờ trong quá trình điều trị NTCT, theo dõi điện tâm đồ là 
cần thiết để phát hiện sớm hạ kali máu. Bổ sung kali trong dịch bù là tối cần thiết để dự phòng hạ kali máu.

Phù não là môt biến chứng nguy hiểm của nhiễm toan ceton [4]. Đây không phải là một biến chứng phổ biến nhưng có thể để lại hậu quả nặng nề. Trẻ em hay gặp biến chứng này hơn so với người lớn. Các triệu chứng của phù não thường xuất hiện trong quá trình điều trị NTCT nhưng có thể xuất hiện trước khi bắt đầu điều trị.

\section{KẾT LUÂN}

Bệnh nhân được chẩn đoán ĐTĐ type 1 lần đầu ở Bệnh viện Nhi Trung ương có tỷ lệ NTCT cao. Nồng độ C-peptid dưới $1,1 \mathrm{ng} / \mathrm{ml}$, chẩn đoán nhầm, trì hoãn điều trị là các yêu tố gây gia tăng nguy cơ và mức độ NTCT. Suy thận cấp là biến chứng hay gặp trong NTCT.

\section{TÀI LIÊU THAM KHẢO}

1. Lee H.J., Yu H.W., Jung H.W., et al (2017). Factors Associated with the Presence and Severity of Diabetic Ketoacidosis at Diagnosis of Type 1 Diabetes in Korean Children and Adolescents. Journal Korean Medical Sciences, 32(2):303.

2. Mayer-Davis E.J., Kahkoska A.R., Jefferies C. et al (2018). ISPAD Clinical Practice Consensus Guidelines 2018: Definition, epidemiology, and classification of diabetes in children and adolescents. Pediatric Diabetes, 19, 7-19.

3. Usher-Smith J.A., Thompson M., Ercole A. et al (2012). Variation between countries in the frequency of diabetic ketoacidosis at first presentation of type 1 diabetes in children: a systematic review. Diabetologia, 55(11), 2878-2894.

4. Wolfsdorf J.I., Glaser N., Agus M., et al (2018). ISPAD Clinical Practice Consensus Guidelines 2018: Diabetic ketoacidosis and the hyperglycemic hyperosmolar state. Pediatric Diabetes, 19, 155-177.

5. Professional Practice Committee 2018.Standards of Medical Care in Diabetes2018.Diabetes Care, 41(Supplement 1), S3-S3.

6. Usher-Smith J.A., Thompson M.J., Sharp S.J. et al (2011). Factors associated with the presence of diabetic ketoacidosis at diagnosis of diabetes in children and young adults: a systematic review. BMJ, 343, d4092-d4092.

7. Varshney GA., Varshney D., Mehr $V$, et al (2015). Clinical profile and outcome of diabetic ketoacidosis in children at tertiary care hospital. Journal Evolution of Medical Dental Sciences, 4(31), 5329-5333.

8. Mohammed A.N (2015)Characteristics of pediatric diabetic ketoacidosis patients in Saudi Arabia.Saudi Medicine Journal, Vol. 36 (1).

9. Rosenbauer J (2002). Clinical characteristics and predictors of severe ketoacidosis at onset of type 1 diabetes mellitus in children in a North Rhine-Westphalian Region, Germany.Journal of Pediatric Endocrinology \& Metabolism, 15, 1137-1145.

\section{SO SÁNH TỶ LÊ BIẾN CỐ CHẢY MÁU, TỶ LÊ BỎ THUỐC VÀ ẢNH HƯởNG TRÊN MỘT SỐ CHİ SỐ HÓA SINH MÁU GIỮA TICAGRELOR VỚI CLOPIDOGREL TRÊN BÊ̂NH NHÂNBI BÊ̂NH ĐộNG MẠCH CHI DƯỚI}

\section{TÓM TẮT}

Hoàn cảnh nghiên cứu: Ticagrelor là môt thuốc kháng kết tập tiểu cầu qua cơ chế ức chế thuận nghịch thụ thể P2Y12. Ưu điểm của thuốc này là không phải chuyển hóa qua gan thành dạng có tác dung dược lý như clopidogrel. Nghiên cứu PLATO trên bểnh nhẩn bị hôi chứng động mạch vành cấp cho thây ticagrelor không những có hiệu quả hơn clopidogrel trong phòng ngừa biến cố tim mach mà thuốc này cũng không làm tăng các biến cố chảy máu. Do đó chúng tôi tiến hành nghiên cứu này trên đối tượng bệnh nhân bị BĐMCD để kiểm chứng xem tỷ lệ biến cố

\section{*Đại Học Y Dược Thái Binh \\ ** Dai Hoc Y Hà Nôi}

Chị trách nhiệm chính: Trần Xuân thủy

Email: bsxuanthuyytb@gmail.com

Ngày nhận bài: 28.12.2020

Ngày phản biên khoa học: 22.2.2021

Ngày duyệt bài: 2.3.2021

\section{Trần Xuân Thủy*, Đinh Thị Thu Hương**}

chảy máu, tỷ lệ bỏ thuốc, ảnh hưởng trên một số chỉ số hóa sinh máu của ticagrelor có thực sự tương đương với clopidogrel hay không? Phương pháp nghiển cứu: Nghiên cứu lâm sàng ngẫu nhiên có đối chứng trên 178 bệnh nhân bị BĐMCD: nhóm nghiên cứu dùng ticagrelor $90 \mathrm{mg} \times 2$ lần/ngày, nhóm chứng dùng clopidogrel $75 \mathrm{mg} / \mathrm{ngày}$. Thời gian theo dõi 18-36 tháng. Tiêu chí nghiên cứu là các biến cố mọi loại chảy máu, xuất huyết não, chảy máu gây tử vong, thời gian dùng thuốc trung bình, tỷ lệ bỏ thuốc và nồng độ một số chỉ số hóa sinh máu. Kết quả: Tỷ lệ mọi loại chảy máu ở nhóm nghiên cứu là 7,8\%; ở nhóm chứng là $6,8 \%$. Sự khác biêt là không có ý nghĩa thống kê với $p=0,79$. Tỷ lệ chảy máu phải truyền máu ở nhóm nghiên cứu là $1,1 \%$; ở nhóm chứng là $2,3 \%$ với $p=0,546$. Có 1 bệnh nhân xuất huyết não ở nhóm chứng. Chúng tôi không găp bênh nhân nào chảy máu gây tử vong ở 2 nhóm. Tỷ lệ bỏ thuốc ở nhóm nghiên cưuu là $12,4 \%$; ở nhóm chứng là $17 \%$, với OR $(\mathrm{CI} 95 \%)=1,46(0,63-3,38)$. Thời gian dùng thuốc trung bình của 2 nhóm khác biệt không có ý nghĩa với $p=0,96$. Nồng độ các chỉ số hóa sinh 